\title{
Work Environment and Service Recovery Performance in Hotel Operations in Egypt
}

\section{Mohamed Kamal Abdien}

\author{
Lecturer - Hotel Studies Departmnet \\ Faculty of Tourism and Hotels, Alexandria University
}

\begin{abstract}
Employees should be encouraged to deal with any mistakes and to satisfy angry customers to keep a long-term relationship with them and keep the hotel's image. Hence, the purpose of this study is to investigate factors that improve service recovery performance (SRP) in hotel operations. A survey was designed and distributed to hotel employees in three departments; front office, housekeeping and restaurant. They were randomly selected from five-star hotels in Egypt. Results indicated that training, empowerment; motivation, organizational support, and service technology are effective elements for work environment and to predict SRP. The study concludes that hotel management should struggle to provide better work environment to their employees to perform service recovery effectively. It emphasized that training, empowerment; motivation, organizational support, and service technology are effective elements for work environment to enhance employees' SRP. Accordingly, the study advises hotels management to provide encouraging work environment for all guest contact employees.
\end{abstract}

Keywords: Work environment; service recovery performance; Egypt

\section{Introduction}

Many mistakes and problems frequently occur in the hospitality industry during offering service to guests. Employees in the hospitality industry have a challenge to deal with guests' problems and complaints, and to not lose them (Schumacher and Komppula, 2016). Losing guests means both profit decrease and negative word of mouth (Filip, 2013). Therefore, all guests' problems and complaints should be recovered to ensure long-term relationships with customers (Michel et al., 2009). When employees offer excellent service recovery, customers will feel satisfied and will do positive actions for the organization (Othman et al., 2013). Service recovery policies should be planned and well-considered and not to be haphazard. It is the responsibility of management to help their employees perform service recovery. It should enhance the working conditions in order to provide a better working environment for employees to perform better (Kiruja and Kabare, 2013). Work environment that involves good training, empowerment, motivation, supportive management, and service technology for frontline employees will encourage employees' service recovery performance and maintain customers' satisfaction (Piaralal et al., 2016). Thus, this study 
seeks to highlight and investigate many factors that can provide helpful work environment to improve service recovery performance (SRP) in hotel operations.

\section{Literature Review}

\subsection{Training}

Training is generally defined as an important process to improve employees' existing skills, knowledge, experience, and abilities (Ameeq and Hanif, 2013; Shaheen et al., 2013; Alfandi, 2016). Training motivates employees to retain in their organization by increasing their satisfaction (Vuta and Facras, 2015; Kesen, 2016). Effective training helps employees develop their personal characters and increase their self confidence to solve problems (Nenna et al. 2013). In addition, training influences the quality and quantity of work and speed of work achievement (Kum et al., 2014; Alfandi, 2016). It was also found that trained employees are more competent and motivated than untrained employees (Manoj, 2013; Asfaw et al., 2015).

Hotel staff has to be well trained continuously to satisfy the customer they contact with (Ameeq and Hanif, 2013). Training ensures the employees' ability to work in the changing business environment or with the new technology (Falola et al., 2014). It also gives employees the skills and experience to cope with more complex situations (Kum et al., 2014). Training is as an investment to get future benefits and also to achieve competitive advantage (Elnaga and Imran, 2013). Moreover, training creates a pleasant work environment that encourages team spirit among employees (Zahra et al., 2014).

\subsection{Empowerment}

Empowerment is defined as the leaders' ability to allow employees have input and control over their work as well as trusting their employees to make some independent decisions (Ramesh, 2014). According to the concept of empowerment, employee can handle customers' complaints and solve their problems in the way he/she sees it suitable (Wamuyu et al., 2015). It is very essential to allow employees to manage failure (Bhandari et al., 2007) and to meet or exceed customers' expectations during the service (Ukil, 2016). Empowerment practices encourage employees to increase their knowledge and skills and to be innovative in handling work (Fernandez and Moldogaziev, 2011). In addition, empowerment is seen as one important element for work environment that influence the service recovery (Masoud and Abu Hmeidan, 2013). In particular, empowerment is more important to hotel front desk operations to deal with frequent and sudden situations or complaints of customers (Yilmaz, 2015). Empowerment helps employees who are in continuous contact with customers take rapid actions for the service recovery (Wamuyu et al., 2015).

\subsection{Motivation}

Motivation is an internal or external driving energy that pushes employees to maximize their efforts to achieve the required tasks (Patterson, 2010). The internal driving energy comes from within an individual while the external energy is generated by the organization (Maduka and Okafor, 2014). In fact, keeping employees motivated and especially under stressful work 
conditions is a great challenge (Manzoor, 2012). Hence, it is very important to motivate employees to deliver the inspired services and to perform their works optimally. It is the role of managers to know their employees very well and adopt new plans to motivate each of them according to their personal wants and needs (Ahmad et al., 2012; Ganta, 2014). Managers also need to remember that motivating employees is a continuous process that fills the vacuum created by a need in the human being (Maduka and Okafor, 2014). They should consider the environment that creates a motivated workforce (Safiullah, 2015). It was found that level of motivation is influenced by the good working environment (Yazdani et al., 2011). If employees feel appreciated for their work, it will increase their productivity and loyalty (Dobre, 2013). Moreover, when employees are well motivated, they are ready for service recovery performance (Cheraghalizadeh, 2014).

\subsection{Organizational Support}

According to Krishnan and Mary (2012), organizational support is an employee's feeling of the extent to which organization is concerned for his/her welfare. It reflects quality of social interactions that occur between employers and their employees (Casper et al., 2011). Organization should develop policies and strategies that improve employees' impressions about the organization (Eisenberger et al., 2016). It is also necessary to pay more attention to their salaries and career promotion; it should distribute rewards fairly among employees and provide fair career opportunities (Alizadeh and Cheraghalizadeh, 2015). Additionally, management should do its efforts to help employees improve their job-related knowledge, skills, abilities, and behaviors (Ibrahim et al., 2016). In fact, organizational support is principal to enhance the employees' job satisfaction the organizational commitment (Woo and Chelladurai, 2012; Alijanpour et al., 2013; Guan et al., 2014). It has a significant impact on employee retention (Iqbal and Hashmi, 2015). When employees feel support from their organization, they feel responsibility to retain for helping it to succeed (Beheshtifar and Heart, 2013). Moreover, this organizational support motivates employees to do voluntary action for the sake of their organizations (Danish et al., 2015). Furthermore, it is a significant factor in generating creativity among their employees to perform good job (Ibrahim et al., 2016).

\subsection{Service Technology}

Recently, information technology has influenced the management and quality of services. It facilitates the delivering of services in more comfortable and rapid ways (Bitner et al., 2010). For example, a computerized system supports employees to carry out their tasks easily (Oluwagbemi et al., 2011). Generally, service technology has a remarkable role in achieving speed of service quality and customer satisfaction (Bakhat, and Aziz, 2012). In particular, by adopting and using technology in hotel sector, service quality can be improved (Koutroumanis, 2011). Nowadays, employees can use many information technology applications to deliver the service to customers effectively and in a competitive way (Bakhat, and Aziz, 2012). Fartash and Gharechedaghi (2012) confirmed that service can be better handled and recovered due to technological shifting in information technology and communication. Accordingly, technology service was found to enable both customers and employees to receive and provide service effectively (Bitner et al., 2010). By using it, employees can access easily to the required data and resources as well as they can contact 
their colleagues. It also helps employees for better customer relationship management (Devi and Jyothsna, 2014). Moreover, adopting service technology in hotel sector enables customers to have a better experience (Bhatt, 2013).

\subsection{Service Recovery performance}

The characteristic of hospitality environment makes service failure is expected from time to time (Ogbonna, and Igbojekwe, 2015). This service failure may cause customer dissatisfaction (Kim et al., 2009). Hence, service recovery plans should be ready in hotels to deal with any mistakes and to satisfy angry customers and to keep a long-term relationship with them (Santos-Vijande et al., 2013). Service recovery performance (SRP) refers to the actions taken by service provider to resolve a service failure (Karatepe and Vatankhah 2015). SRP may not always resolve service failures, but it can reduce its harmful effect (Varela-Neira et al., 2010). SRP handles problems in two possible states: before a customer's complaints and after his complains (Gronroos, 2007). Hence, CSR helps organizations turn its unhappy customers into satisfied and loyal (Smith et al, 2012). SRP is considered as a part of service quality that should be enhanced to assure excellence service quality is provided to customers (Rejikumar, 2015). Moreover, the organization's reputation depends on the level of SRP presented to its customers (Hassan, 2015).

Recovery activities may include apologies, explanations and substitutions (Edvardsson et al., 2011). Service providers should provide their customers with number of potential resolutions that enhance responsiveness in recovery situation (Smith et al., 2012). Compensation is also one of the most important service recovery strategies that are used in hotels (Wamuyu et al., 2015). Actually, service provider should adopt different SRP approaches depending upon the nature of the problem as well as the type of customers (Lai and Chou, 2015). Moreover, effective communication and quickness in SRP are necessary to overcome customer dissatisfaction (Rejikumar, 2015). Organizations can encourage employees' SRP by providing a convenient and motivating work environment. Masoud and Hmeidan, (2013) indicated that training, empowerment, motivation, supportive management, and service technology can motivate frontline employees' SRP. Rewards, team work, job satisfaction are also found important for motivating employees' SRP (Malhotra and Lages, 2015; Nadiri, and Tanova, 2016; Mahyoub et al., 2017).

\section{Hypotheses of the Study}

Based on the previous literatures, this study has the following hypotheses to test:

H1 : Work environment positively influences the employees' services recovery performance.

H1a: Training positively influences the employees' services recovery performance.

H1b: Empowerment positively influences the employees' services recovery performance.

H1c : Motivation positively influences the employees' services recovery performance.

H1d: organizational support positively influences the employees' services recovery performance.

H1e: Service technology positively influences the employees' services recovery performance.

$\mathrm{H} 2$ : Services recovery performance is varied significantly according to the hotel department. 


\section{Methodology of the Study}

\subsection{Samples and Data Collection Method}

The target population for the research is all 5-star chain-affiliated hotels in Egypt. A survey was designed and distributed to employees of these hotels; they were randomly selected. 900 questionnaires were distributed among employees who are in contact with guests; front office department, housekeeping department and restaurants. 715 questionnaires were answered and returned, but only 640 were valid for analysis, counting for $71 \%$ of the total sample, representing a satisfying response rate.

\subsection{Variables and Measures}

The survey consists of two parts; the first part is related to the respondents' demographic data and the second part is related to measure the study's variables and is divided to six sections; the first section measures training and involves 5 items; the second measures "empowerment" and involves 4 items; the third measures "motivation" and involves 4 items; the fourth section measures "organizational support" and involves 5 items; the fifth section measures "service technology" and involves 4 items and the sixth section measures "service recovery performance" and involves 5 items. All these items were measured using a 5-item scale ranging from "strongly disagree" (1) to "strongly agree" (5). The first five sections represent the independent variables while the sixth section represents the dependent variable. All participants confirmed that they are in contact with guests in their work.

\section{Results}

\subsection{Reliability Analysis}

First, the survey was pre-tested to identify items that are not clear to participants and to avoid any mistakes that might lead to biased answers. Second, Cronbach's Alpha test was conducted as seen in table 1. The closer the Cronbach's Alpha is to 1, the higher the internal consistency reliability (Sekaran, 2003). The analysis showed that Cronbach Alpha values for all constructs are high which means their high reliability.

Table 1: Reliability Analysis

\begin{tabular}{lll}
\hline The constructs of the study & N & Cronbach's Alpha \\
\hline Training & 5 & .937 \\
Empowerment & 4 & .821 \\
Motivation & 4 & .902 \\
Organizational support & 5 & .924 \\
Service technology & 4 & .954 \\
Service recovery Performance & 5 & .929 \\
\hline
\end{tabular}

\subsection{Respondents' Profile}

Table 2 shows that $63 \%$ of respondents were male and $37 \%$ were females, the majority (67\%) was graduated from college, and $80 \%$ were aged between 20 to 40 years. $30 \%$ of participants are 
working in the front office department, $31 \%$ are working in the hotel restaurants and $39 \%$ are working in the housekeeping department. Respondents were asked about how many years of experience they had in the hotel industry; 56\% answered they had experience less than 5 years, $36 \%$ had experience from 5 to ten years and only $8 \%$ had experience more than 10 years.

Table 2: Description of Respondents' Profile

\begin{tabular}{llll}
\hline Respondents' Profile & & N & \% \\
\hline \multirow{2}{*}{ Gender } & Male & 202 & 63 \\
& Female & 118 & 37 \\
\cline { 2 - 4 } Educational level & Under secondary school & 23 & 7 \\
& Secondary school & 71 & 22 \\
& College & 214 & 67 \\
& Other & 12 & 4 \\
Age & $20-30$ & 125 & 39 \\
& $31-40$ & 132 & 41 \\
& $41-50$ & 53 & 17 \\
Years of Experience & Above 50 & 10 & 3 \\
& Less than 5 & 180 & 56 \\
\multirow{2}{*}{ Department } & 5-10 & 115 & 36 \\
& More than 10 & 25 & 8 \\
\cline { 2 - 4 } & Front office & 97 & 30 \\
& Housekeeping & 124 & 39 \\
& Restaurants & 99 & 31 \\
\hline
\end{tabular}

\subsection{Descriptive Analysis of the Variables}

Table 3 presents the mean scores and attitudes for the study constructs. It is seen that empowerment as an element of work environment is the most perceived by respondents (4.44), followed by training (4.24), followed by organizational support (3.87), followed by service technology (3.83) and employee motivation is the least perceived (3.65). The total mean score of work environment is high. Moreover, Respondents showed that they do service recovery practices highly.

Table 3: Mean Scores and Attitudes of the Study Variables

\begin{tabular}{llll}
\hline The study variables & Mean & Std. Deviation & Attitude \\
\hline Work environment & 4.00 & .42 & Agree \\
1. $\quad$ Empowerment & 4.44 & .70 & Strongly agree \\
2. Training & 4.24 & .64 & Strongly agree \\
3. $\quad$ Organizational support & 3.87 & .25 & Agree \\
4. $\quad$ Service technology & 3.83 & .64 & Agree \\
5. Motivation & 3.65 & .41 & Agree \\
Service recovery performance & 4.18 & .49 & Agree \\
\hline
\end{tabular}




\subsection{Data Analysis and Testing Hypotheses}

A correlation analysis (table 4) was done on all constructs to determine if there are significant correlations. The result showed that work environment correlates significantly and positively with $\mathrm{SRP}$, it recorded $\mathrm{p}$ value less than .001. All elements of work environment; training, empowerment, motivation, organizational support and service technology correlate significantly and positively with SRP, they all recorded $\mathrm{p}$ value less than .001 .

Table 4: Pearson Correlation Analysis

\begin{tabular}{lll}
\hline & & Service Recovery performance \\
\hline Training & Pearson Correlation & $.391^{* *}$ \\
& Sig. (2-tailed) & .000 \\
Empowerment & Pearson Correlation & $.460^{* *}$ \\
& Sig. (2-tailed) & .000 \\
Motivation & Pearson Correlation & $.622^{* *}$ \\
Organizational & Sig. (2-tailed) & .000 \\
Support & Pearson Correlation & $.720^{* *}$ \\
Service Technology & Sig. (2-tailed) & .000 \\
& Pearson Correlation & $.868^{* *}$ \\
Work Environment & Sig. (2-tailed) & .000 \\
& Pearson Correlation & $.737^{* *}$ \\
& Sig. (2-tailed) & .000 \\
\hline
\end{tabular}

$* * \overline{\text { Correlation is significant at the } 0.01 \text { level }(2}$

Regression analysis (table 5) was also performed to predict the level of SRP based on work environment. According to the results, work environment correlates and influences significantly with service recovery performance $(\mathrm{R}=.737$, sig.000). It was noted that about $54 \%$ of the variance could be predicted by work environment. The changes of 1 unit in the work environment will cause a change of 0.856 units in the SRP. Hence, H1 is supported. The results also showed that all elements of work environment (training, empowerment, motivation, organizational support and service technology) influence significantly the SRP. Results showed that training caused about $15 \%$ of the variance in SRP. The changes of 1 unit in the training will cause a change of 0.301 units in the SRP. Hence, H1a is supported. Empowerment caused $21 \%$ of the variance in SRP. The changes of 1 unit in empowerment will cause a change of 0.322 units in the SRP. Hence, H1b is supported. Motivation caused about 39\% of the variance in SRP. The changes of 1 unit in motivation will cause a change of 0.746 units in SRP. Hence, H1c is supported. Organizational support caused about $52 \%$ of the variance in SRP. The changes of 1 unit in support will cause a change of 1.418 units in SRP. Hence, H1d is supported. Moreover, the strongest correlation was found between service technology and SRP $(\mathrm{R}=.868$, sig. $=.000)$. It was noted that about $75 \%$ of variance could be predicted by Service technology. The changes of 1 unit in service technology will cause a change of 0.670 units in SRP. Hence, H1e is supported. Although organizational support $(B=1.418)$ had the greatest effect on SRP followed by motivation $(B=.746)$ and service technology $(\mathrm{B}=0.670)$. However, training $(\mathrm{B}=0.301)$ had the smallest effect and followed by empowerment $(\mathrm{B}=0.322)$. 
Table 5: Regression Analysis

\begin{tabular}{llllllll}
\hline & & R & R Square & Adjusted R Square & B & Sig. & Hypotheses \\
\hline \multicolumn{1}{l}{ Work environment } & $.737^{\mathrm{a}}$ & .543 & .542 & .856 & .000 & H1 supported \\
$\mathbf{1}$ & Training & $.391^{\mathrm{a}}$ & .153 & .150 & .301 & .000 & H1a supported \\
$\mathbf{2}$ & Empowerment & $.460^{\mathrm{a}}$ & .212 & .209 & .322 & .000 & H1b supported \\
$\mathbf{3}$ & Motivation & $.622^{\mathrm{a}}$ & .387 & .385 & .746 & .000 & H1c supported \\
$\mathbf{4}$ & Organizational & $.720^{\mathrm{a}}$ & .518 & .517 & 1.41 & .000 & H1d supported \\
& support & & & & 8 & & \\
$\mathbf{5}$ & Service technology & $.868^{\mathrm{a}}$ & .753 & .752 & .670 & .000 & H1e supported \\
\hline
\end{tabular}

Kruskal-Wallis test was conducted to see if there are significant variances among respondents' SRP based on the department they work. Results in table 6 showed that employees' SRP varied significantly ( $\mathrm{p}$. value $=.015$ ) based on their department. It was found that front office employees' SRP was the highest (mean rank $=180.49$ ) followed by housekeeping employees' SRP (mean rank = 157.66) while restaurant employees' SRP was the lowest. Hence, H2 is supported.

Table 6: Kruskal-Wallis Test

\begin{tabular}{llllll}
\hline & & Mean Rank & Chi-Square df & Sig. Hypotheses \\
\hline \multirow{3}{*}{ Hotel Department } & Front office & 180.49 & & & \\
& Housekeeping & 157.66 & 8.341 & 2 & .015 H2 supported \\
& Restaurant & 144.47 & & & \\
\hline
\end{tabular}

\section{Discussion}

Findings demonstrated that work environment elements were positively related to SRP separately and jointly. These results are agreed with Masoud and Hmeidan (2013) as they found that training, empowerment, motivation, organizational support, and service technology significantly predict frontline employees' SRP. It is possible to properly manage hotel employees' SRP by producing the right working environment for them (Masdek et al., 2011; Doh, 2013). If leaders provide their employees with the good working environment, employees will be able to service customer better (Kiruja and Kabare, 2013).

This study emphasized the importance of fife elements for an effective SRP. First, training was found in this study to be a significant element of work environment to influence SRP. Previous studies found that trained employees were more prepared and experienced than untrained employees to recover services (Manoj, 2013; Asfaw et al., 2015; Mahyoub et al., 2017). It is needed to provide employees with foundational skills in order to deal with the complicated customers' problems and complaints. Second, empowerment was also found to be a significant element of work environment to influence SRP. It allows employees to be innovative in handling guests' matters (Fernandez and Moldogaziev, 2011). Hotels should give more empowerment to their front-line employees to deal with service failures. Empowerment was seen important to enable employees to offer suitable clarifications for the failure and take rapid actions for the SRP (Wamuyu et al., 2015). Third, motivation was found a significant element of work environment to 
influence SRP. Employees need motivation to be satisfied to perform their works optimally (Ganta, 2014). If employees are motivated for their work, it will lead to better SRP (Masoud and Hmeidan, 2013). Fourth, organizational support was a significant element of work environment to influence SRP. When employees become aware of their organizations' attention, admiration, support and respect towards them, they show positive return to that (Beheshtifar et al., 2012). Furthermore, this support may create motivate employees to do voluntary action for the sake of SRP (Masoud and Hmeidan, 2013; Danish et al., 2015). Finally, service technology was found a significant element of work environment to influence SRP. Using service technology efficiently in organizations has a great role in achieving speed of service quality and customer satisfaction (Bakhat and Aziz, 2012). Service can be better recovered due to technological changing in information technology and communication (Fartash and Gharechedaghi, 2012; Masoud and Hmeidan, 2013). By using technology, employees can access easily to the required data and resources as well as they can contact their colleagues (Devi and Jyothsna, 2014).

In this study, SRP varied according to the department. Front office employees were found to adopt more SRP than housekeeping and restaurants employees. Hence, all frontline employees in all departments should be more trained, empowered, motivated, supported and provided with technology service in equal manner to enhance their future SRP.

\section{Conclusion}

This study provides a clear and convincing evidence of the unique effects of service recovery performance since the characteristic of hospitality environment makes service failure is expected from time to time. Hotels must adopt service recovery plans to create a long-term relationship with their customers. Hence, it should struggle to provide better work environment to their employee. This study emphasized that training, empowerment; motivation, organizational support, and service technology are effective elements for work environment to enhance employees' SRP. Employees should be trained to get the required knowledge and skills to recover any expected failure as well as to deal with expected and unexpected situations. Employees should also be empowered to take independent decisions to deal with frequent and sudden situations or complaints of customers and take rapid actions for SRP. In addition, managers should do their best to motivate their employees intrinsically and extrinsically, employees who are motivated are expected to satisfy and exceed customers' needs. Moreover, management should feel their employees enough support and concern. When employees feel their organizations' attention, admiration, support and respect; they may do voluntary action in recovering service effectively. Finally, this study confirmed that service can be better handled and recovered due to service technology. By using technology, employees can access easily to the required data and resources as well as they can contact their colleagues for rapid SRP.

\section{Limitations and Future Researches}

This study highlighted only five elements for better work environment, future researches may study other elements that not included in this study. Moreeover, the study investigated the antecedents of SRP; future researches may investigate its consequences as well. 


\section{References}

Ahmad, M. B., Wasay, E. \& Malik, S. (2012). Impact of employee motivation on customer satisfaction: study of airline industry in Pakistan, Interdisciplinary Journal of Contemporary Research in Business, 4(6), 531-539.

Alfandi, A. M. (2016). Training impact on the performance of employees: a case of Jordanian travel and tourism institutions, International Business Management, 10(4), 377-384.

Alijanpour, M. Dousti, M. \& Khodayari, A. (2013). The relationship between the perceived organizational support and organizational commitment in staff (A case study: General office for sport and the youth, Mazandaran province), European Journal of Experimental Biology, 3(5), 165-171.

Alizadeh, R. C. \& Cheraghalizadeh, R. (2015). The effect of organizational supports on job performance construction projects, Electronic Journal of Vocational Colleges-December/Aralık, pp. 86-91.

Ameeq, A. \& Hanif, F. (2013). Impact of training on employee's development and performance in hotel industry ofn Lahore, Pakistan, Journal of Business Studies Quarterly. 4 (4), 69-82.

Asfaw, A. M. Argaw, M. D. \& Bayissa, L. (2015). The impact of training and development on employee performance and effectiveness: A case study of district five administration office, Bole Sub-City, Addis Ababa, Ethiopia, Journal of Human Resource and Sustainability Studies, 3(4), 188-202.

Bakhat, M. S. \& Aziz, S. (2012). The impact of information technology and hospitality services on customer satisfaction-a case study of fast food industry in Pakistan, Interdisciplinary journal of contemporary research in business, 4(6), 360-390.

Beheshtifar, M. \& Heart, B. H. (2013). To promote employees commitment via perceived organizational support, International Journal of Academic Research in Business and Social Sciences, 3(1), 306-313.

Beheshtifar. M., Nezhad, H. A. \& Moghadam, M. N. (2012). Investigation of perceived organizational support on employees' of positive attitudes towards work interdisciplinary, Journal of Contemporary Research Business, 4 (8), $432-442$.

Bhatt, L. M. (2013). Hospitality industry and the role of information technology, Indian journal of research, 3 (5), 1-3.

Bhandari, M. S., Tsarenko, Y. \& Polonsky, M. J. (2007). A proposed multi-dimensional approach to evaluating service recovery, Journal of Services Marketing, 21 (3), 174-185.

Bitner, M. J., Zeithaml, V. A. \& Gremler, D. D. (2010). Handbook of Service Science. New York: Springer.

Casper, W. J., Harris, C., Taylor-Bianco, A. \& Wayne, J. H. (2011). Work-family conflict, perceived supervisor support and organizational commitment among Brazilian professionals, Journal of Vocational Behavior, 79(3), 640652.

Cheraghalizadeh, R. (2014). The Effect of intrinsic motivation on job satisfaction: mediation role of service recovery performance, International Journal of Economic Practices and Theories, 4(5), 511-517.

Danish, R. Q., Humayon, A. A., Shahid, A. U., Ahmad, H. W. \& Murtaza, G. (2015). Relationship between perceived organizational support and organizational citizenship behavior; a study of employees in national highway authority of Pakistan, American Journal of Economics, Finance and Management, 1 (3), 195-199.

Devi, V. R. \& Jyothsna, M. (2014). Impact of technology on employee engagement-detrimental or beneficial, Pacific business review international, 7(4), 10-12.

Dobre, O. (2013). Employee motivation and organizational performance, Review of Applied Socio- Economic Research, 5(1), 53-60.

Doh, W. L. (2013). Antecedents of service recovery performance in 3 and 4 Star hotels in Douala, Cameroon (Published master's thesis). Eastern Mediterranean University, Gazimağusa, North Cyprus. 
Edvardsson, B., Tronvoll, B., \& Ykinpuro, R. H. (2011). Complex service recovery processes: how to avoid triple deviation, Managing Service Quality, 21(4), 331-349.

Eisenberger, R., Malone, G. P. \& Presson, W. D. (2016). Optimizing perceived organizational support to enhance employee engagement. SHRM-SIOP Science of HR Series.

Elnaga1, A. \& Imran, A.(2013). The Effect of training on employee performance, European Journal of Business and Management, 5(4), 137-147.

Falola, H. O., Osibanjo, A. O. \&. Ojo, S. I. (2014). Effectiveness of training and development on employees' performance and organization competitiveness in the Nigerian banking industry, Economic Sciences, 7(1), 161-170.

Fartash, A. \& Gharechedaghi, N. (2012). Evaluating the effect of contact center on customer satisfaction in Iran, Journal of Basic and Applied Scientific Research, 2(3), 2872-2880.

Fernandez, S. \& Moldogaziev, T. (2011). Empowering public sector employees to improve performance: does it work? The American Review of Public Administration, 41 (1), 23-47.

Filip, A. (2013). Complaint management: A customer satisfaction learning process, Procedia - Social and Behavioral Sciences, 93, $271-275$.

Ganta, V. C. (2014). Motivation in the workplace to improve the employee performance, International Journal of Engineering Technology, Management and Applied Sciences, 2 (6), 221, 230.

Gronroos, C. (2007). Service Management and Marketing. Chichester: Wiley.

Guan, X., Sun, T., Hou, Y. Zhao, L., Luan, Y. \& Fan, L. (2014). The relationship between job performance and perceived organizational support in faculty members at Chinese universities: a questionnaire survey, BMC Medical Education, 1450, 1-10.

Hassan, A. (2015). Consequences of service recovery: evidences from public sector of Pakistan, Journal of Business and Management, 17(5), 65-72.

Ibrahim, H. I., Isa, A. \& Shahbudin, A. (2016). Organizational support and creativity: The role of developmental experiences as a moderator, Procedia Economics and Finance, 35, 509-514.

Iqbal, S. \& Hashmi, M. S. (2015). Impact of perceived organizational support on employee retention with mediating role of psychological empowerment, Pakistan Journal of Commerce and Social Sciences, 9 (1), 18-34.

Karatepe, O. M., \& Vatankhah, S. (2015). High-performance work practices, career satisfaction, and service recovery performance: a study of flight attendants, Tourism Review, 70 (1), 56-71.

Kesen, M. (2016). The impact of employee training and innovation on turnover intention: an empirical research, International Journal of Academic Research in Business and Social Sciences, 6(1), 174-185.

Kim, T., Kim, W. G., \& Kim, H. B. (2009). The effects of perceived justice on recovery satisfaction, trust, word-ofmouth, and revisit intention in upscale hotels, Tourism Management, 30(1), 51-62.

Kiruja E. K. \& Kabare, K. (2013). Linking work environment with employee performance in public middle level TIVET institutions in Kenya, International Journal of Advances in Management and Economics, 2(4), 83-91.

Koutroumanis, D. A. (2011). Technology's effect on hotels and restaurants: building a strategic competitive advantage, Journal of Applied Business and Economics, 12(1), 77, 80.

Krishnan, J., \& Mary, V. S. (2012). Perceived organizational support: an overview on its antecedents and consequences, International Journal of Multidisciplinary Research, 2 (4), 1016-1022.

Kum, F. D., Cowden, R. \& Karodia, A. M. (2014). The impact of training and development on employee performance: a case study of Escon consulting Singaporean, Journal of business economics and management studies, $3(3), 72-105$. 
Lai, M. C. \& Chou, F. S. (2015). The relationships among involvement level, service failure, service recovery disconfirmation and customer lifetime value, Journal of Economics, Business and Management, 3(4), $452-457$.

Maduka, C. E. \& Okafor, O. (2014). Effect of motivation on employee productivity: a study of manufacturing companies in Newi, International Journal of Managerial Studies and Research, 2(7), 137-147.

Mahyoub, M. M., Farea, M. M. \& Bardai, B. (2017). The impact of human resource management practices on service recovery performance among telecommunication companies in Yemen, The International Journal of Business and Management, 5(1), 59-65.

Malhotra, N. \& Lages, C. R. (2015). Frontline Service Recovery Performance Through the Lens of Organizational Support Theory: Exploring the Role of POS and Felt Obligation, The international research conference in service management, a Londe les Maures, France May 27, 28, 29 \& 302014.

Manoj, A. S. (2013). A study on the efficiency of training in hospitality - A Kerala tourism development corporation (KTDC) experience, Trivandrum Kerala, International Journal of Advanced Research in Management and Social Sciences, 7(4), 171-186.

Manzoor, Q. (2012). Impact of employees motivation on organizational effectiveness, European Journal of Business and Management, 3(3), 36-44.

Masdek, N. R., Abdul Aziz, Y. \& Awang, K. W. (2011). Potential antecedents and outcomes of frontline employees' service recovery performance, International Journal of Economics and Management, 5(1), 114 -139.

Masoud, E. Y. \& Abu Hmeidan, T. (2013). The effect of perceived work environment on frontline employees' service recovery performance: the case of four and five star hotels in Jordan, European Scientific Journal, 9(11), 129-147.

Michel, S., Bowen, S., and Johnston, R. (2009). Why service recovery fails: tensions among customer, employee, and process perspectives, Journal of Service Management, 20(3), 253-273.

Nadiri, H. and Tanova, C. (2016). What factors influence employee service recovery performance and what are the consequences in health care? Quality Management in Health Care, 25(3), 162-175.

Nenna E. Ukandu, N. E. \& Ukpere, W. I. (2013). Effects of poor training and development on the work performance of the fast food employees in Cape Town, Mediterranean Journal of Social Sciences, 4(14), 571-579.

Ogbonna, C. O. \& Igbojekwe, P. A. (2015). Evaluation of service recovery strategies in some hotels in Lagos Metropolis, Lagos, Nigeria, Indian Journal of Commerce and Management Studies, VI(2), 57-63.

Oluwagbemi, O., Joshua, A. and Philip, A. (2011). The Impact of information technology in Nigeria's banking industry, Journal of Computer Science and Engineering, 7(2), 63-67.

Othman, Z., Zahari, M. S. \& Radzi, A. M. (2013). Customer Behavioral Intention: influence of service delivery failures and service recovery in Malay restaurants, Procedia - Social and Behavioral Sciences, 105, 115 - 121.

Patterson, C. (2010). Management Briefs: Management and Leadership Theory Made Simple. London: BookBoon.

Piaralal, S. K., Bhatti, M. A., Piaralal, N. K. \& Juhari, A. S. (2016). Factors affecting service recovery performance and customer service employees: a study of Malaysian life insurance industry, International Journal of Productivity and Performance Management, 65(7), 898 - 924.

Ramesh, K. (2014). Role of employee empowerment in organizational development. iInternational, Journal of Scientific Research and Management, 2(8), 1241-1245.

Rejikumar, G. (2015). An empirical study on antecedents of perceived service recovery quality in E-banking context, Journal of Internet Banking and Commerce, 20(3), 1-24.

Safiullah, A. B. (2015). Employee motivation and its most influential factors: A study on the telecommunication industry in Bangladesh, World Journal of Social Sciences, 5(1), 79 - 92. 
Santos-Vijande, M. L., Diaz-Martin, A. M., Suarez-Alvarez, L., \& Del Rio-Lanza, A. B. (2013). An integrated service recovery system (ISRS): influence on knowledge-Intensive business services performance, European Journal of Marketing, 47(5/6), 934-963.

Schumacher, S. \& Komppula, R. (2016). A case study on service recovery: Frontline employees' perspectives and the role of empowerment, European Journal of Tourism, Hospitality and Recreation, 7(2), 117-127.

Sekaran, U. (2003). Research Methods for Business: A Skill-Building Approach. Fourth edition. New York: John Wiley \& Sons,

Shaheen, A., Naqvi, S. M. \& Khan, M. A. (2013). Employees training and organizational performance: mediation by employees performance, Interdisciplinary. Journal of contemporary research in business, 5(4), 490-503.

Smith, J. S., Nagy, P. F., Karwan, K. R., \& Ramirez, E. (2012). The contingent nature of service recovery system structures, International Journal of Operations \& Production Management, 32(7), 877-903.

Ukil, M. I. (2016). The impact of employee empowerment on employee satisfaction and service quality: empirical evidence from financial enterprises in Bangladesh, Business: Theory and Practice, 17(2), 178-189.

Varela-Neira, C., Vazquez-Casielles, R. \& Iglesias, V. (2010). The effects of customer age and recovery strategies in a service failure setting, Journal of Financial Services Marketing, 15(1), 32-48.

Vuta, D. R. \& Facras, A. (2015). The role of training in organizational and employee development, Management and Economics, 3(79), 367-372.

Wamuyu, S. N., Gichira, R., Wanjau, K. L. \& Mungatu, J. (2015). Employee empowerment in service recovery and customer loyalty in the hospitality industry in Kenya, International Journal of Economics, Commerce and Management, 3(9), 27-41.

Woo B. \& Chelladurai, P. (2012). Dynamics of perceived support and work attitudes: the case of fitness club employees, Human Resource Management Research, 2(1), 6-18.

Yazdani, B. O., Yaghoubi, N. M., \& Giri, E. S. (2011). Factors affecting the empowerment of employees, European Journal of Social Sciences, 20(2), 267-274.

Zahra, S., Iram, A. and Naeem, H. (2014). Employee training and its effect on employees' job motivation and commitment: developing and proposing a conceptual model, Journal of Business and Management, 16(9), 60-68. 